\title{
Interleukin-10-592 polymorphism: impact on relapse and survival after allogeneic hematopoietic stem cell transplantation in children with hematological malignancies
}

\author{
Laura Schwenk $^{1} \cdot$ Susan Wittig ${ }^{1} \cdot$ Bernd Gruhn $^{1}$ (D) \\ Received: 18 April 2021 / Accepted: 13 June 2021 / Published online: 21 June 2021 \\ (c) The Author(s) 2021
}

\begin{abstract}
Purpose Interleukin-10 (IL-10) potentially can promote the development of alloimmunity. The aim of this study was to investigate if the IL-10-592 CC genotype in the donor reduces the risk of relapse after hematopoietic stem cell transplantation (HSCT) and if that has an impact on event-free survival (EFS) and overall survival (OS).

Methods A cohort of 211 children with acute lymphoblastic leukemia $(n=99)$, acute myeloid leukemia $(n=69)$, myelodysplastic syndrome $(n=31)$ or chronic myeloid leukemia $(n=12)$ who underwent hematopoietic stem cell transplantation (HSCT) in a single center and their respective donors were genotyped of IL-10 gene for rs 1800872 using TaqMan real-time polymerase chain reaction.

Results The IL-10-592 CC genotype was detected in 107 of the 211 donors (50.7\%) and in 106 of the 211 patients (50.2\%). Genotype AC was found in 95 donors (45.0\%) and in 90 patients (42.7\%). Nine donors (4.3\%) and 15 patients $(7.1 \%)$ were homozygous for AA. Ultimately, we observed a significantly reduced incidence of relapse rate (RR) in patients who were transplanted from a donor with the IL-10-592 CC genotype (19\% versus $43 \%$ (AC) versus $49 \%$ (AA); $P=0.0007$ ). In addition, a significant increase of EFS $(P=0.004)$ and OS $(P=0.006)$ was detected if the IL-10-592 CC genotype is present in the donor. The occurrence of the IL-10-592 CC genotype, in either donors or recipients, had no significant impact on acute and chronic graft-versus-host disease. In addition, the IL-10-592 genotype of the recipients was not relevant for the RR $(P=0.47434)$, the EFS $(P=0.840)$, and the OS $(P=0.535)$.

Conclusion The IL-10-592 CC genotype in the donor was associated with a significant decrease of RR which led to a significant increase of EFS and OS after HSCT. This is the first study to describe an association of the IL-10 gene polymorphism with RR, EFS, and OS after HSCT. Selecting a donor with the IL-10-592 CC genotype could be a useful therapeutic strategy for improving the outcome after allogeneic HSCT.
\end{abstract}

Keywords Interleukin 10 - Single nucleotide polymorphism • Allogeneic hematopoietic stem cell transplantation · Children $\cdot$ Relapse rate $\cdot$ Event-free survival

\section{Introduction}

Leukemia is the most common malignant disease in childhood. The majority of patients with leukemia are cured by means of chemotherapy. High-risk patients with a greater risk of relapse or patients with high-risk relapse require a more intensive therapy. The allogeneic hematopoietic

Bernd Gruhn

Bernd.Gruhn@med.uni-jena.de

1 Department of Pediatrics, Jena University Hospital, Am Klinikum 1, 07747 Jena, Germany stem cell transplant (HSCT) is an efficient strategy to treat those patients. However, this treatment also includes various risks, such as graft-versus-host disease (GVHD), infections, hepatic sinusoidal obstruction syndrome, and relapse (Hierlmeier et al. 2018; Dukat-Mazurek et al. 2017). To avoid those complications an appropriate donor is desirable (Lin et al. 2003). Ideally, the donor should transmit a graft-versus-leukemia (GVL) effect, but should not induce a GVHD (Seggewiss and Einsele 2010). Interleukin-10 (IL10 ) is an antiphlogistic homodimer, consisting of 160 amino acids, belonging to the group of the cytokines (Wei et al. 2019). In 1989, after experiments with laboratory mice, IL-10 was described as a cytokine synthesis inhibiting factor 
produced by type 2T-helper cells (Fiorentino et al. 1989). Furthermore, IL-10 inhibits the secretion of cytokines of type 1T-helper cells (Fiorentino et al. 2016). In addition to the type 2T-helper cells, IL-10 is also produced by multiple other cell types, including monocytes, B cells, dendritic cells (Sabat et al. 2010), keratinocytes (Enk and Katz 1992), and tumor cells (Asadullah et al. 2000).

The human IL-10 gene is located on chromosome 1q31q32, consists of five exons and has a molecular weight of $18.5 \mathrm{kDa}$ (Zhang and Kuchroo 2019). The effect of IL-10 is mediated by the binding to the IL-10 receptor which is a specific transmembrane receptor (Moore et al. 2001). The IL-10 receptor (IL-10R) is composed of two subunits, which both belong to the class 2 cytokine receptors, IL10R1 (formed by hematopoietic stem cells) and IL-10R2 (expressed ubiquitously) (Walter 2014). Acuner-Ozbabacan et al. (2014) described IL-10 as a well-known immunomodulatory cytokine within the immune system. The characteristics of IL-10 are still disputed throughout medical publications, and IL-10 is described by numerous authors as a paradoxical cytokine (Mannino et al. 2015; Geginat et al. 2019; Wang et al. 2013). It is acknowledged and scientifically proven that IL-10 has immunosuppressive effects by inhibiting the production of various cytokines (IL-1 $\alpha$, IL-1 $\beta$, IL-6, IL-10 itself, TNF, GM-CSF, G-CSF, M-CSF, LIF, PAF), CC chemokines (MCP-1, MCP-5, CCL5) and CXC chemokines (IL-8, IP-10, MIP-2) by monocytes and macrophages (de Vries 1995; Zheng et al. 2020). In addition, IL-10 influences the expression of MHC class II molecules and CD86/CD80 in antigen-presenting cells (Mittal and Roche 2015), the expression of MHC class I molecules in tumor cells (Salazar-Onfray et al. 1997), the expression of costimulatory molecules on dendritic cells and regulates the IL-12 production (Rahim et al. 2005). IL-10 has an immunosuppressive effect, yet, contradicting this statement, in the context of malignant diseases there are numerous investigations on in vitro and in vivo laboratory mice which prove the immune support of the IL-10's function (Zheng et al. 1996; Mocellin et al. 2005). These investigations demonstrate that IL-10 stimulates an anti-tumor cytotoxic reaction and therefore a tumor regression leading to the prevention of metastases formation. These results also include the ability of IL-10 to increase the cell count of CD8 + T cells, the increase of interferon gamma's secretion and the induction of cytotoxicity in tumors (Lauw et al. 2000). Furthermore IL-10 was able to decrease the growth of tumors and to generate the rejection of the tumors (Berman et al. 1996).

As far as we know, for the first time, we analyzed the influence of IL-10 polymorphism on the relapse rate (RR), the event-free survival (EFS), and the overall survival (OS) after allogeneic HSCT. We were particularly interested in examining the impact of IL-10 single nucleotide
Table 1 Characteristics of patients and donors $(\mathrm{n}=211)$

\begin{tabular}{|c|c|}
\hline Characteristics & Total, No (\%) \\
\hline Median age of the patients (y) & 11 \\
\hline Age range & 5 months -18 years \\
\hline \multicolumn{2}{|l|}{ Sex of the patients } \\
\hline Male & $123(58.3)$ \\
\hline Female & $88(41.7)$ \\
\hline \multicolumn{2}{|l|}{ Disease } \\
\hline Acute lymphoblastic leukemia & 99 (46.9) \\
\hline Acute myeloid leukemia & $69(32.7)$ \\
\hline Chronic myeloid leukemia & $12(14.7)$ \\
\hline Myelodysplastic syndrome & $31(14.7)$ \\
\hline \multicolumn{2}{|l|}{ Remission (complete) } \\
\hline First & $65(30.8)$ \\
\hline Second & $42(19.9)$ \\
\hline Third & $14(6.6)$ \\
\hline Not in remission & $90(42.7)$ \\
\hline \multicolumn{2}{|l|}{ Conditioning regimen (based on) } \\
\hline Total body irradiation & $107(50.7)$ \\
\hline Busulfan & $104(49.3)$ \\
\hline \multicolumn{2}{|l|}{ Donor type } \\
\hline HLA-matched unrelated & $108(51.2)$ \\
\hline HLA-mismatched unrelated & $26(12.3)$ \\
\hline HLA-identical related & $61(28.9)$ \\
\hline HLA-haploidentical related & $16(7.6)$ \\
\hline \multicolumn{2}{|l|}{ GvHD } \\
\hline aGvHD II-IV & $74(35.1)$ \\
\hline aGvHD III-IV & $30(14.2)$ \\
\hline cGvHD & $36(17.1)$ \\
\hline \multicolumn{2}{|l|}{ Stem cell source } \\
\hline Bone marrow & $121(57.3)$ \\
\hline Peripheral blood stem cells & $90(42.7)$ \\
\hline \multicolumn{2}{|c|}{ Donors' IL-10 polymorphism distribution } \\
\hline $\mathrm{CC}$ & $107(50.7)$ \\
\hline $\mathrm{AC}$ & $95(45.0)$ \\
\hline AA & $9(4.3)$ \\
\hline
\end{tabular}

polymorphism (SNP) rs 1800872 as a possible factor for the decrease of RR after HSCT.

\section{Patients and methods}

\section{Patients}

We analyzed 211 patients together with their donors at the Department of Pediatrics, Jena University Hospital, Jena, Germany. The patients suffered from the following diseases: acute myeloid leukemia (AML), acute lymphoblastic leukemia (ALL), chronic myeloid leukemia (CML) and 
myelodysplastic syndrome (MDS). The patients' characteristics are shown in Table 1.

\section{Genotyping of IL-10 polymorphism}

For the genotyping of IL-10 polymorphism DNA was isolated from the patients' blood or bone marrow aspirates using High Pure PCR Template Preparation Kit (Roche, Mannheim, Germany) according to the manufacturer's instructions. The DNA concentration was measured at 260 and $280 \mathrm{~nm}$ using BioPhotometer plus provided by Eppendorf (Wesseling-Berzdorf, Germany). The mixture consisted of $1 \mu \mathrm{L}(10 \mathrm{ng} / \mu \mathrm{L}) \mathrm{DNA}, 10 \mu \mathrm{L}$ Genotyping Mastermix, $9.5 \mu \mathrm{L}$ sterile aqua, and $0.5 \mu \mathrm{L}$ primer-probe mix (TaqMan Genotyping Assays provided by Applied Biosystems, Foster City, CA, USA). We transferred at least five negative controls together with the samples using pipettes into 96-well optical reaction plates marked with barcodes. We used the 7900HT Fast Real-Time PCR System by Applied Biosystems to subject the DNA to an absolute quantification process by proceeding with the following: heating of the samples for $10 \mathrm{~min}$ at $95^{\circ} \mathrm{C}$ to activate the mixture immediately followed by 40 cycles of $15 \mathrm{~s}$ duration at $92{ }^{\circ} \mathrm{C}$ to denaturize the DNA and finishing with $60 \mathrm{~s}$ at $60{ }^{\circ} \mathrm{C}$ to anneal and extend the DNA. Subsequently, the SNP was analyzed through an allelic discrimination post-read run. The investigated SNP in this process was rs1800872 (IL-10-592).

\section{Statistical analysis}

We aimed to find a potential association between the analyzed IL-10-592 polymorphism and the RR, EFS, and OS. We used the Kaplan-Maier method for providing maximum accuracy concerning the calculations of the EFS and OS. With the help of the log-rank test we were able to identify all differences between results. OS was defined as the duration between HSCT and the death of the patient. Subsequently, EFS was defined as the duration between HSCT and any of the following events: relapse, secondary malignancy, or death. For the analysis of the RR, survival calculations with competing risk were used. The Gray test (Gray 1988) was used for evaluating differences between the statistical curves. $\mathrm{RR}$ was defined as the cumulative incidence of relapse. For all calculations, IBM SPSS Statistics 26 and R Foundation for Statistical Computing 4.0.2. were used. The $P$ value below 0.05 was considered as statistically significant. We performed multivariate analyses for the identification of potential confounding variables such as gender match, disease risk, and acute graft-versus-host disease grade (GVHD) II-IV. The disease risk was low if the patients were transplanted in complete first or second remission. The disease risk was high if the transplantation was performed in more than second remission or in relapse (Arndt et al. 2014).

\section{Results}

\section{Allocation of polymorphism}

In total, we included 211 donors and 211 recipients in our examinations. While analyzing the information of all donors, we observed the homozygous genotype CC in 107 donors (50.7\%), the heterozygous genotype AC in 95 donors (45.0\%), and the homozygous genotype AA in 9 donors (4.3\%). The IL-10-592 CC genotype was detected in 106 of the 211 recipients (50.2\%). Genotype AC was found in 90 patients $(42.7 \%)$ and 15 patients $(7.1 \%)$ were homozygous for AA.

\section{Relapse rate (RR)}

The analysis of the donors' IL-10-592 SNP showed that the genotype CC was associated with a decreased RR. Only $19 \%$ of the patients who received a transplant from a donor with genotype CC suffered from relapse compared to $43 \%$ or $49 \%$ of patients who received a transplant from a donor with genotype $\mathrm{AC}$ or AA, respectively $(P=0.0007$; Fig. 1$)$.

\section{Event-free-survival (EFS)}

We observed a significant association between the genotype of the donor and the EFS. The EFS was $60.7 \%$ if the patient was transplanted from a donor with the genotype CC. On the other hand, the EFS was only $38.9 \%$ or $22.2 \%$ if the patient

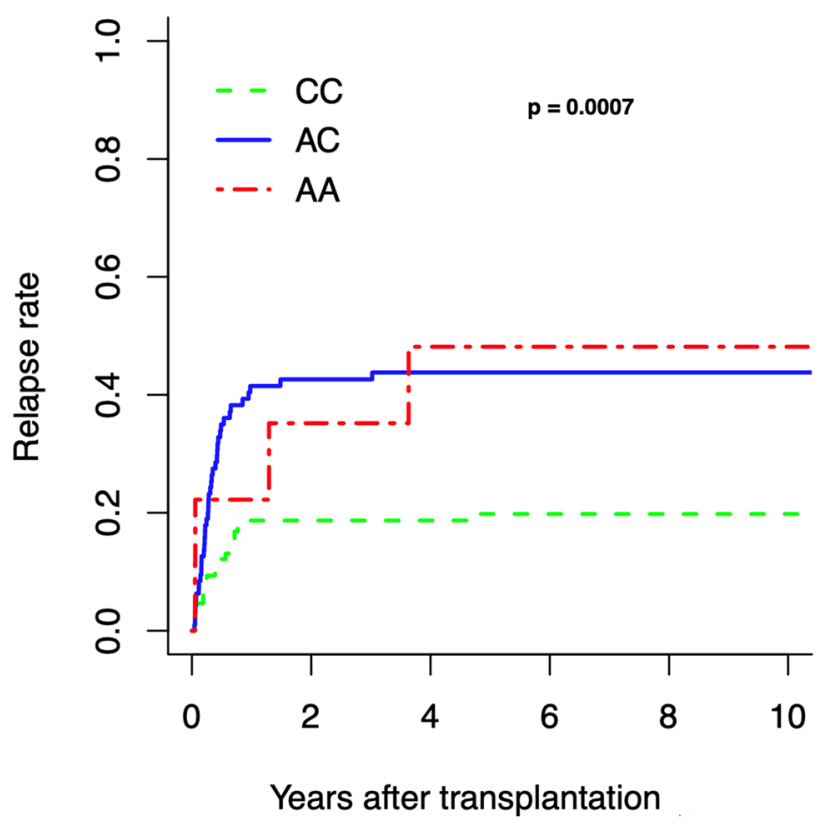

Fig. 1 Relapse rate according to donor's SNP rs1800872 status 
was transplanted from a donor with the genotype AC or AA, respectively ( $P=0.004$; Fig. 2$)$.

\section{Overall survival (OS)}

We found a significant association between the donors' genotype and the OS. The OS was $63.3,43.2$, or $22.2 \%$ if the patient was transplanted from a donor with the IL-10592 genotype $\mathrm{CC}, \mathrm{AC}$ or $\mathrm{AA}$, respectively $(P=0.006$; Fig. 3). In addition, the IL-10-592 genotype of the recipients was not relevant for the RR $(P=0.47434)$, the EFS $(P=0.840)$, and the OS $(P=0.535)$.
Fig. 2 Event-free survival according to donor's SNP rs1800872 status
Fig. 3 Overall survival according to donor's SNP rs1800872 status
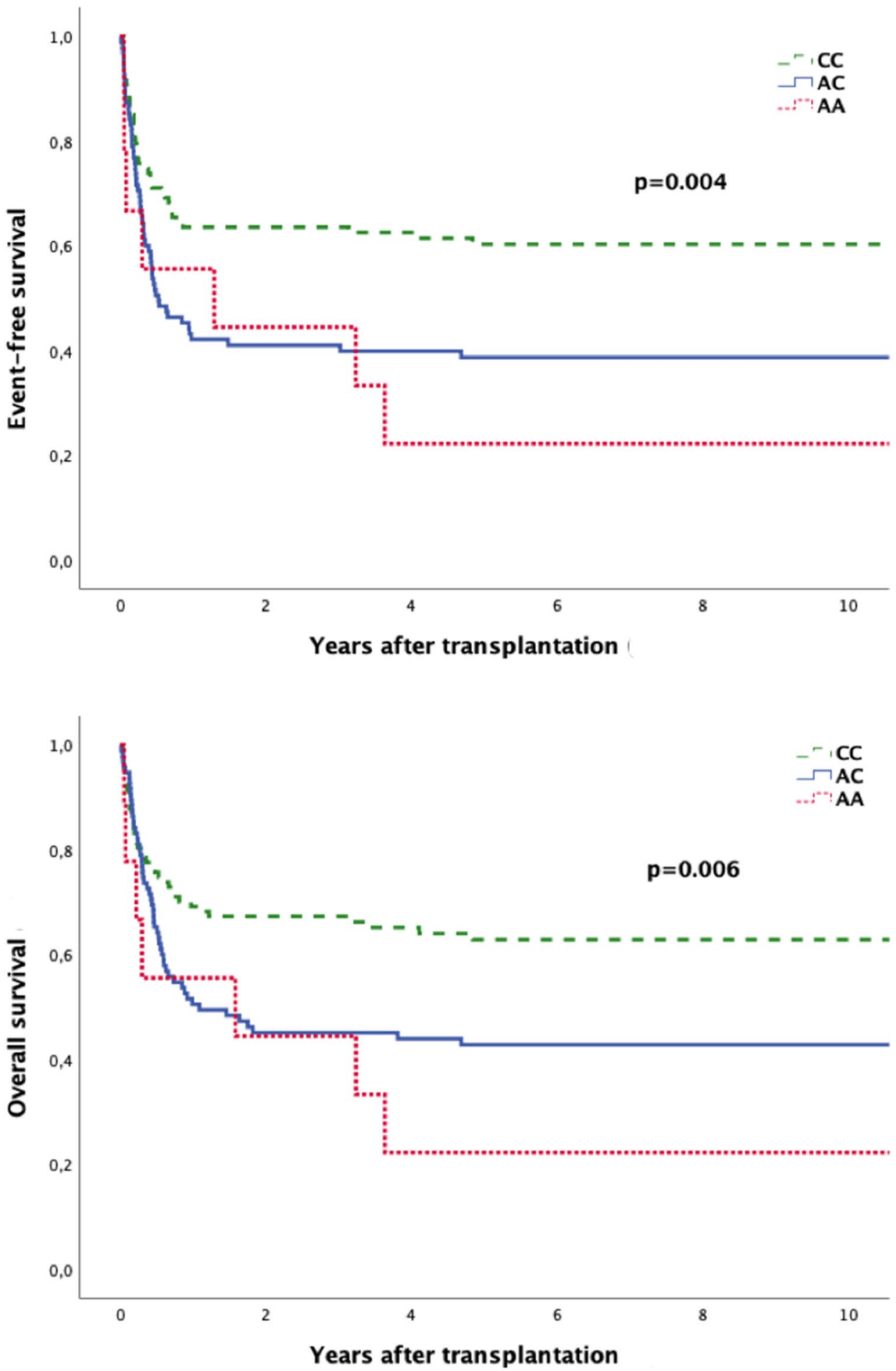
Table 2 Multivariate analysis. Relapse rate (RR) and eventfree survival (EFS)

\begin{tabular}{|c|c|c|c|c|}
\hline \multirow[t]{2}{*}{ Variable } & \multicolumn{2}{|l|}{$\mathrm{RR}$} & \multicolumn{2}{|l|}{ EFS } \\
\hline & HR (95\% CI) & $P$ & HR $(95 \%$ CI $)$ & $P$ \\
\hline Donor IL10- (rs1800872) & $0.438(0.241-0.797)$ & 0.007 & $0.592(0.396-0.886)$ & 0.011 \\
\hline Gender match & $1.464(0.844-2.538)$ & 0.175 & $1.447(0.962-2.176)$ & 0.076 \\
\hline Disease risk & $0.001(0.0-1.321)$ & 0.760 & $0.255(0.167-0.391)$ & 0.001 \\
\hline Stem cell source & $1.494(0.871-2.562)$ & 0.144 & $1.526(1.029-2.265)$ & 0.036 \\
\hline Conditioning regimen & $0.994(0.599-1.650)$ & 0.982 & $0.856(0.579-1.264)$ & 0.433 \\
\hline HLA compatibility & $1.226(0.438-3.432)$ & 0.698 & $0.515(0.231-1.152)$ & 0.106 \\
\hline Acute GVHD grade II-IV & $1.504(0.864-2.617)$ & 0.149 & $1.038(0.693-1.554)$ & 0.858 \\
\hline
\end{tabular}

$G V H D$ graft-versus-host disease, $H L A$ human leukocyte antigen

\section{Multivariate analysis}

Multivariate analysis was used to prove whether the association between the donor's IL-10-592 polymorphism and RR and EFS was influenced by other factors. To assess whether IL-10-592 SNP is an independent prognostic factor, we incorporated the following possible confounding variables: donor-recipient-gender match, disease risk, stem cell source, conditioning regimen, HLA compatibility, and the occurrence of acute GVHD grade II to IV. The results are presented in Table 2 and demonstrate that the IL-10-592 SNP is an independent significant risk factor for RR and EFS.

\section{Discussion}

This retrospective study demonstrates that IL-10-592 polymorphism $\mathrm{CC}$ of the donor had a significant impact on the RR $(P=0.0007)$, the EFS $(P=0.004)$ and the OS $(P=0.006)$.

Additionally, we examined the impact of the IL-10-592 polymorphism CC on the acute and chronic GVHD. However, we did not observe a significant association between the values. In our study, we found that the genotype CC provides a strong protection against relapse leading to a significant increase of EFS and OS. IL-10 is a central immunomodulatory cytokine. Previous studies have demonstrated that IL-10 leads to the formation of cytotoxic $\mathrm{T}$ lymphocytes and activation of B cells by upregulation of specific genes in toll-like-receptor-activated macrophages and dendritic cells (Lang et al. 2002; Iyer and Cheng 2012).

The immunostimulatory effects of IL-10 were also examined by other authors in malignant diseases (Suzuki et al. 1995; Mosser and Zhang 2008). IL-10 stimulation promotes a T-cell activation and the differentiation of CD8 + T cells (Mannino et al. 2015). This activation of T cells could be the explanation of the reduced RR which we have found in our study. After the treatment with IL-10, patients showed a significant decrease of interleukin-1 (IL-1) and increased interferon-gamma levels (Tilg et al.
2002; Lauw et al. 2000). Until now, IL-1 has been known as a proangiogenic cytokine and promoter of tumor formation (Voronov et al. 2007). The transfection of tumor cells with IL-10 or another systemic therapy of IL-10 suppressed the tumor growth and caused tumor rejection. In addition, the genetic ablation of IL-10 in the mouse increased the sensitivity to chemical carcinogenesis, augmented the growth of transplanted tumors and accelerated the formation of metastases (Berti and Brajão de Oliveira 2018). The tumor-microenvironment consists of regulatory $\mathrm{T}$ cells, dysfunctional antigen-presenting cells and myeloid-derived suppressor cells. Exactly those cells create an immunosuppressive network and can therefore promote tumor growth. We want to highlight that the cytokine IL-10 hampers the development of previously mentioned cells.

In conclusion, IL-10 is responsible for inhibiting tumor development, tumor growth and formation of metastases. Furthermore, IL-10 can regulate inflammatory cytokine production. Aborsangaya et al. (2007) has demonstrated that the IL-10-592 CC genotype causes a higher production rate of IL-10 than the CA- or AA-genotype. These observations agree with our results that the genotype IL-10-592 CC in the donor induced a significant decrease of RR as well as a significant increase of EFS and OS after HSCT in children with hematological malignancies. To our knowledge, this is the first study to describe an association of IL-10 gene polymorphism with RR after HSCT. Selecting a donor with the IL-10-592 CC genotype could be useful therapeutic strategy for improving the outcome after allogeneic HSCT. Additionally, further studies are necessary to confirm our results.

Funding Open Access funding enabled and organized by Projekt DEAL.

\section{Declarations}

Conflict of interests The authors declare that they have no conflict of interest. 
Ethical standards All procedures were in accordance with the ethical standards. The study has been approved by the Jena University Hospital Ethics Committee (2021-2088). Informed consent was obtained from all individual participants or the responsible persons included in the study.

Open Access This article is licensed under a Creative Commons Attribution 4.0 International License, which permits use, sharing, adaptation, distribution and reproduction in any medium or format, as long as you give appropriate credit to the original author(s) and the source, provide a link to the Creative Commons licence, and indicate if changes were made. The images or other third party material in this article are included in the article's Creative Commons licence, unless indicated otherwise in a credit line to the material. If material is not included in the article's Creative Commons licence and your intended use is not permitted by statutory regulation or exceeds the permitted use, you will need to obtain permission directly from the copyright holder. To view a copy of this licence, visit http://creativecommons.org/licenses/by/4.0/.

\section{References}

Aborsangaya KB, Dembinski I, Khatkar S, Alphonse MP, Nickerson P, Rempel JD (2007) Impact of aboriginal ethnicity on HCV core-induced IL-10 synthesis: interaction with IL-10 gene polymorphisms. Hepatology 45(3):623-630. https://doi.org/ 10.1002/hep. 21511

Acuner-Ozbabacan ES, Engin BH, Guven-Maiorov E, Kuzu G, Muratcioglu S, Baspinar A, Chen Z, Van Waes C, Gursoy A, Keskin O, Nussinov R (2014) The structural network of Interleukin-10 and its implications in inflammation and cancer. BMC Genomics 15(Suppl 4):S2. https://doi.org/10.1186/ 1471-2164-15-s4-s2

Arndt C, Beck JF, Gruhn B (2014) A pediatric prognostic score for patients undergoing allogeneic hematopoietic stem cell transplantation. Eur J Haematol 93(6):509-515. https://doi.org/10.1111/ ejh. 12390

Asadullah K, Döcke WD, Volk HD, Sterry W Interleukin-10 als immunsuppressives Zytokin: Bedeutung für die Dermatologie. In, Berlin, Heidelberg, 2000. Dermatologie an der Schwelle zum neuen Jahrtausend. Springer Berlin Heidelberg, pp 13-16

Berman RM, Suzuki T, Tahara H, Robbins PD, Narula SK, Lotze MT (1996) Systemic administration of cellular IL-10 induces an effective, specific, and long-lived immune response against established tumors in mice. J Immunol 157(1):231-238

Berti F, Brajão de Oliveira K (2018) IL-10 in cancer: just a classical immunosuppressive factor or also an immunostimulating one? AIMS Allergy Immunol 2:88-97. https://doi.org/10.3934/Aller gy.2018.2.88

de Vries JE (1995) Immunosuppressive and anti-inflammatory properties of interleukin 10. Ann Med 27(5):537-541. https://doi.org/10. 3109/07853899509002465

Dukat-Mazurek A, Bieniaszewska M, Hellmann A, Moszkowska G, Trzonkowski P (2017) Association of cytokine gene polymorphisms with the complications of allogeneic haematopoietic stem cell transplantation. Hum Immunol 78(11):672-683. https://doi. org/10.1016/j.humimm.2017.09.005

Enk AH, Katz SI (1992) Identification and induction of keratinocytederived IL-10. J Immunol 149(1):92-95

Fiorentino DF, Bond MW, Mosmann TR (1989) Two types of mouse T helper cell IV Th2 clones secrete a factor that inhibits cytokine production by Th1 clones. J Exp Med 170(6):2081-2095. https:// doi.org/10.1084/jem.170.6.2081
Fiorentino DF, Zlotnik A, Vieira P, Mosmann TR, Howard M, Moore KW, O'Garra A (2016) IL-10 Acts on the Antigen-presenting Cell to Inhibit Cytokine Production by Thl Cells. J. Immunol. 1991. 146: 3444-3451. J Immunol 197 (5):1531-1538

Geginat J, Vasco M, Gerosa M, Tas SW, Pagani M, Grassi F, Flavell RA, Meroni P, Abrignani S (2019) IL-10 producing regulatory and helper T-cells in systemic lupus erythematosus. Semin Immunol 44:101330. https://doi.org/10.1016/j.smim.2019.101330

Gray RJ (1988) A class of K-sample tests for comparing the cumulative incidence of a competing risk. Ann Stat 16(3):1141-1154

Hierlmeier S, Eyrich M, Wölfl M, Schlegel PG, Wiegering V (2018) Early and late complications following hematopoietic stem cell transplantation in pediatric patients-a retrospective analysis over 11 years. PLoS ONE 13(10):e0204914. https://doi.org/10.1371/ journal.pone.0204914

Iyer SS, Cheng G (2012) Role of interleukin 10 transcriptional regulation in inflammation and autoimmune disease. Crit Rev Immunol 32(1):23-63. https://doi.org/10.1615/critrevimmunol.v32.i1.30

Lang R, Patel D, Morris JJ, Rutschman RL, Murray PJ (2002) Shaping gene expression in activated and resting primary macrophages by IL-10. J Immunol 169(5):2253-2263. https://doi.org/10.4049/ jimmunol.169.5.2253

Lauw FN, Pajkrt D, Hack CE, Kurimoto M, van Deventer SJ, van der Poll T (2000) Proinflammatory effects of IL-10 during human endotoxemia. J Immunol 165(5):2783-2789. https://doi.org/10. 4049/jimmunol.165.5.2783

Lin MT, Storer B, Martin PJ, Tseng LH, Gooley T, Chen PJ, Hansen JA (2003) Relation of an interleukin-10 promoter polymorphism to graft-versus-host disease and survival after hematopoietic-cell transplantation. N Engl J Med 349(23):2201-2210. https://doi. org/10.1056/NEJMoa022060

Mannino MH, Zhu Z, Xiao H, Bai Q, Wakefield MR, Fang Y (2015) The paradoxical role of IL-10 in immunity and cancer. Cancer Lett 367(2):103-107. https://doi.org/10.1016/j.canlet.2015.07.009

Mittal SK, Roche PA (2015) Suppression of antigen presentation by IL-10. Curr Opin Immunol 34:22-27. https://doi.org/10.1016/j. coi.2014.12.009

Mocellin S, Marincola FM, Young HA (2005) Interleukin-10 and the immune response against cancer: a counterpoint. J Leukoc Biol 78(5):1043-1051. https://doi.org/10.1189/jlb.0705358

Moore KW, de Waal MR, Coffman RL, O'Garra A (2001) Interleukin-10 and the interleukin-10 receptor. Annu Rev Immunol 19:683-765. https://doi.org/10.1146/annurev.immunol.19.1.683

Mosser DM, Zhang X (2008) Interleukin-10: new perspectives on an old cytokine. Immunol Rev 226:205-218. https://doi.org/10. 1111/j.1600-065X.2008.00706.x

Rahim SS, Khan N, Boddupalli CS, Hasnain SE, Mukhopadhyay S (2005) Interleukin-10 (IL-10) mediated suppression of IL-12 production in RAW 264.7 cells also involves c-rel transcription factor. Immunology 114(3):313-321. https://doi.org/10.1111/j. 1365-2567.2005.02107.x

Sabat R, Grütz G, Warszawska K, Kirsch S, Witte E, Wolk K, Geginat J (2010) Biology of interleukin-10. Cytokine Growth Factor Rev 21(5):331-344. https://doi.org/10.1016/j.cytogfr.2010.09.002

Salazar-Onfray F, Charo J, Petersson M, Freland S, Noffz G, Qin Z, Blankenstein T, Ljunggren HG, Kiessling R (1997) Down-regulation of the expression and function of the transporter associated with antigen processing in murine tumor cell lines expressing IL-10. J Immunol 159(7):3195-3202

Seggewiss R, Einsele H (2010) Immune reconstitution after allogeneic transplantation and expanding options for immunomodulation: an update. Blood 115(19):3861-3868. https://doi.org/10.1182/ blood-2009-12-234096

Suzuki T, Tahara H, Narula S, Moore KW, Robbins PD, Lotze MT (1995) Viral interleukin 10 (IL-10), the human herpes virus 4 cellular IL-10 homologue, induces local anergy to allogeneic and 
syngeneic tumors. J Exp Med 182(2):477-486. https://doi.org/10. 1084/jem.182.2.477

Tilg H, van Montfrans C, van den Ende A, Kaser A, van Deventer SJ, Schreiber S, Gregor M, Ludwiczek O, Rutgeerts P, Gasche C, Koningsberger JC, Abreu L, Kuhn I, Cohard M, LeBeaut A, Grint P, Weiss G (2002) Treatment of Crohn's disease with recombinant human interleukin 10 induces the proinflammatory cytokine interferon gamma. Gut 50(2):191-195. https://doi.org/10.1136/ gut.50.2.191

Voronov E, Carmi Y, Apte RN (2007) Role of IL-1-mediated inflammation in tumor angiogenesis. Adv Exp Med Biol 601:265-270. https://doi.org/10.1007/978-0-387-72005-0_28

Walter MR (2014) The molecular basis of IL-10 function: from receptor structure to the onset of signaling. Curr Top Microbiol Immunol 380:191-212. https://doi.org/10.1007/978-3-662-43492-5_9

Wang Y, Liu XH, Li YH, Li O (2013) The paradox of IL-10-mediated modulation in cervical cancer. Biomed Rep 1(3):347-351. https:// doi.org/10.3892/br.2013.69
Wei H, Li B, Sun A, Guo F (2019) Interleukin-10 family cytokines immunobiology and structure. Adv Exp Med Biol 1172:79-96. https://doi.org/10.1007/978-981-13-9367-9_4

Zhang H, Kuchroo V (2019) Epigenetic and transcriptional mechanisms for the regulation of IL-10. Semin Immunol 44:101324. https://doi.org/10.1016/j.smim.2019.101324

Zheng LM, Ojcius DM, Garaud F, Roth C, Maxwell E, Li Z, Rong H, Chen J, Wang XY, Catino JJ, King I (1996) Interleukin-10 inhibits tumor metastasis through an NK cell-dependent mechanism. J Exp Med 184(2):579-584. https://doi.org/10.1084/jem.184.2.579

Zheng Z, Huang G, Gao T, Huang T, Zou M, Zou Y, Duan S (2020) Epigenetic changes associated with interleukin-10. Front Immunol 11:1105. https://doi.org/10.3389/fimmu.2020.01105

Publisher's Note Springer Nature remains neutral with regard to jurisdictional claims in published maps and institutional affiliations. 